\title{
THE INFLUENCE OF CSR AND ETHICAL SELF-IDENTITY IN CONSUMER EVALUATION OF COBRANDS
}

This is a pre-publication version. Please download the final version at:

http://link.springer.com/article/10.1007/s10551-015-2594-4

\author{
Jaywant Singh \\ Associate Professor in Marketing \\ Kingston Business School, Kingston University \\ Kingston upon Thames, Surrey KT2 7LB \\ United Kingdom \\ Tel: +44(0) 2084175158 \\ Email: J.Singh@kingston.ac.uk
}




\begin{abstract}
An important aspect of brand perception emanates from its corporate social responsibility (CSR) activity. When two brands involved in CSR activities form a cobranding alliance, their respective CSR perceptions can impact consumer attitudes towards the alliance. As an ethically-oriented strategy, the alliance can be potentially beneficial to both partner brands, and can create opportunities for promoting CSR activities. The research streams on brand management, cobranding and CSR, however, are silent about this important branding strategy that has several embedded business and societal benefits. This study examines how CSRbased consumer perceptions and ethical self-identity impact consumer evaluation of cobrands. Employing a quasi-experimental between subjects design, the study tests six cobranding scenarios in three product categories. The data were collected via structured questionnaires resulting in 318 valid responses. The data were analyzed employing the Partial Least Squares Structural Equation Modeling. The results confirm that positive CSR perceptions towards the partner brands are robust indicators of attitudes towards cobrands. Further, the match between the CSR activities of the partner brands (positive CSR fit) and the product categories (product fit) influence cobrand attitudes. The results also show evidence of 'spill-over' effects, where the alliance has a positive impact on subsequent CSR

perceptions towards the partner brands. Additionally, the findings demonstrate an asymmetry in the effects of the cobrand on subsequent CSR perceptions wherein consumers with low ethical self-identity show greater spill-over effects from the cobrand than those with high ethical self-identity. The study contributes to knowledge in the domains of business ethics, cobranding and social responsibility. The findings have managerial implications for designing CSR-based ethical branding strategies for cobrands.
\end{abstract}

Keywords: corporate social responsibility, cobranding, ethical self-identity, partial least squares structural equation modeling, spill-over effects 


\section{THE INFLUENCE OF CSR AND ETHICAL SELF-IDENTITY IN CONSUMER EVALUATION OF COBRANDS}

\section{Introduction}

Consumer awareness on ethical production and commercialization of brands is growing, and in response companies are seeking to integrate ethical behaviour into their business model. An example of this strategic reorientation is the branding strategy based on corporate social responsibility (CSR) activities that are now integral for many companies (Alcaniz, Caceres and Peres, 2010). Companies seeking ethical associations with consumers are creating brand alliances concerning societal issues. For instance, MTV and Body Shop recently teamed up to spread AIDS awareness. Alliances such as MTV and Body Shop not only benefit from the standard brand attributes, but also from the CSR perceptions resulting from the synergistic partnership between two CSR-active brands. Alliances resulting from CSR-active brands can be powerful signaling tools for the brands to differentiate and create effective ethical positioning.

The concept of brand alliance or cobranding is well-known in the domain of strategic brand management. Cobranding combines competencies and reputations of two brands to innovate and create new products (e.g., Gammoh and Voss, 2013; Kalafatis, Riley and Singh, 2014; Newmeyer, Venkatesh and Chatterjee, 2014). In this strategy, a firm enters into complementary partnerships with other firms, or offers innovative new products that benefit from the relative strength of each partner. The success of cobranding is demonstrated by numerous examples that range from short-term programs such as cooperative advertising and joint promotions (e.g., Apple and Starbucks' promotion of free Wifi and iTunes download at Starbucks), dual branding (e.g., Shell and Burger King gas stations), ingredient branding (e.g., Philadelphia cream cheese with Milka), to the introduction of completely new cobranded products (e.g., consumer durables - Senseo, a coffee machine by Philips and 
Douwe Egberts; automobiles - a special edition car by Fiat and Gucci; consumer packaged goods - oral care products by Colgate and Omron).

The proliferation of cobranded products in the marketplace has attracted the attention of branding researchers. A number of studies published in leading marketing journals have examined how cobranded products are evaluated by consumers (e.g., Desai and Keller, 2002; Lafferty, Goldsmith and Hult, 2004; Helmig, Huber and Leeflang, 2008; Olsen and Lanseng, 2012). The empirical results demonstrate a variety of benefits associated with cobranding strategy. For example, alliances can lead to improvement of the parent brand and signal quality (Rao, Qu and Ruekert, 1999; Voss and Gammoh, 2004), the reputation and brand equity of the partner brands are significantly greater when the brands are combined (Washburn Till and Priluck, 2000; Kalafatis, Remizova, Riley and Singh, 2012), consumer attitudes toward the parent brands are transferable to the cobrand (Simonin and Ruth, 1998), favourable attitudes toward the cobrand may lead to trial and purchase probability (Swaminathan, Reddy and Dommer, 2012), and partner brands' positioning strategies influence cobrand evaluation (Singh, Kalafatis and Ledden, 2014). Thus, brand alliances are shown to have both direct effects on attitudes toward the cobrand as well as spill-over effects on post-exposure attitudes toward the partnering brands (e.g., Simonin and Ruth, 1998; Baumgarth, 2004; Lafferty et al., 2004).

Despite the above advances in knowledge on cobranding, the current literature does not address the impact of perceptions of CSR activities of partner brands on consumer evaluation of cobrands. Increasingly, brands are supporting a wide range of CSR activities such as provision of healthcare, education, safe drinking water, and wildlife protection following altruistic corporate motives as well as for conveying to the stakeholders about their inclination towards societal welfare. In this regard, a number of prior studies show that CSR activities influence consumer perceptions of the brand (e.g., Bhattacharya and Sen, 2004; Lii 
and Lee, 2012; Marin, Ruiz and Rubio, 2009; Singh, Sanchez and del Bosque, 2008).

Notwithstanding its relevance and the above advances, the impact of consumer perceptions towards the partner brands' CSR activities is so far not known. In the context of cobranding, another crucial issue is how consumers perceive the complementarity (or the fit) of the CSR activities of the partner brands. This is defined as the 'CSR fit' in this study. This complementarity of perceptions related to the CSR activities of the partner brands and the emergent cobrand is important for the success of the cobrand, yet it has not been studied so far. Further, a positively evaluated cobrand is known to strengthen the attitudes towards the partner brands too (the spill-over effect) (e.g., Lafferty, 2007; Simonin and Ruth, 1998). The crucial question of spill-overs in the context of CSR activities based perceptions, however, has not been addressed yet.

Moreover, the growing awareness of CSR activities relates to perceptions of a consumer's self with regards to ethics, and raises the question whether CSR and cobrand evaluations are influenced by personal attributes such as ethical self-identity (Klein and Dawar, 2004). For example, in the case of Body Shop and MTV, consumer's level of ethicality or CSR consciousness influences consumer brand evaluations and responses to different CSR initiatives (Russel and Russel, 2010). This view is also supported by Helmig et al. (2008), who call for further empirical investigation on the moderating impact of consumer characteristics in cobrand evaluation.

The above issues are central to understanding the interface between consumer perceptions of CSR activities and cobranding. This study, therefore, aims to examine the impact of positive CSR perceptions of partner brands on cobrand evaluation. Grounded in information integration and attitude accessibility theories from social psychology, the study attempts to contribute to knowledge in the domains of CSR and cobranding. First, it investigates the impact of CSR perceptions on consumer cobrand evaluation and subsequent 
spill-over effects for the partner brands. Second, the study examines the role of the complementary of perceptions towards partner brands' CSR activities (CSR fit) as an antecedent of cobrand attitude. Third, the study examines the role of interactions between the predictors of cobrand evaluation (the interactions between the partner brands' CSR perceptions, CSR fit and product fit). Finally, the study investigates whether consumers' ethical self-identity has a moderating role in the evaluation of cobrands resulting from CSRactive partner brands.

The results of this study provide knowledge for brand managers intending to leverage from their brand's CSR activities through alliances, and give insights into how CSR perceptions can influence cobrand success. As suggested by Lafferty (2007), alliances that provide evidence of good corporate citizenship can enhance a company's corporate image as well as have a positive impact on consumer product and brand evaluations. The benefits associated with cobranding explain the increasing engagement of companies in alliances that are designed towards enhancing favorable brand images, and in creating a CSR-based positioning of the partner brands. The results in this study are, therefore, relevant for managers focusing on ethical positioning for their cobrand comprising of CSR perceptions of the partners brand.

The paper begins by offering a review of the current understanding of theoretical underpinnings of the impact of CSR perceptions in cobranding, followed by hypotheses development. Methodology and results are presented thereafter. The paper concludes with a discussion on theoretical contributions and managerial implications, along with limitations and further research directions.

\section{Theoretical Background and Hypotheses Development}


A key issue in consumer research on CSR is the identification of the outcomes of CSR perceptions. Prior research focuses on the effects of CSR on consumer response to product and brand evaluation (Berens, van Riel and van Bruggen, 2005; Brown and Dacin, 1997), customer satisfaction (Luo and Bhattacharya, 2006, 2009; Mohr and Webb, 2005), customer donations (Lichtenstein, Drumwright and Braig, 2004), brand loyalty (Marin, Ruiz and Rubio, 2009), and purchase intentions (Mohr and Webb, 2005). Additionally, a company's CSR involvement is shown to have a positive impact on consumer attitudes toward that company (Brown and Dacin, 1997; He and Li, 2011; Klein and Dawar, 2004; Lii and Lee, 2012; Marin et al., 2009). More generally, in the domain of ethical consumerism, studies have shown that information on ethical product features may have a significant impact on ethical purchase intentions, even though the intentions might not translate into actual behaviour (e.g., Auger, Burke, Devinney and Louviere, 2003; Luzar and Cosse, 2003).

CSR perceptions are, therefore, non-product based and signal symbolic benefits which relate to "underlying needs for social approval, personal expression and out directed selfesteem" (Keller, 1993, p. 4). For example, the positioning of several successful cobrands such as the Rouge berry fragrance by Body Shop and MTV (a brand partnership to raise funds and awareness about HIV and AIDS amongst young people) or the smoothie drink by Innocent and McDonald's (a brand partnership to encourage children to opt for healthier options) are built upon symbolic rather than general brand attitudes. Thus, it may be postulated that positive CSR perceptions of the partner brands prior to the alliance would influence the evaluation of the cobrand.

In cobranding research, post-alliance evaluation of the partner brands is often found to be stronger than the pre-alliance evaluation, and is known as the 'spill-over' effect. A number of empirical studies have confirmed significant spill-over effects in cobranding (e.g., Simonin and Ruth, 1998; Washburn, Till and Priluck, 2004; Baumgarth 2004; Singh et al., 
2014). The effect is explained by the associative network theory postulated by Anderson (1983). In this regard, Keller (1987) suggests that the spill-over effect is a psychological mechanism relating to the activation of one node and its associated elements on other related nodes in a network, which, in turn, is strengthened through pre-existing links between the nodes. In cobranding, spill-over effects arise when consumer pre-alliance attitudes toward the brand is transferred to the subsequent attitudes toward the partner brands.

An explanation for the post-alliance spillover towards the partner brands is suggested by Ajzen and Fishbein (1980) who demonstrate that attitudes are relatively stable psychological constructs. With regard to the cobrand based on partner brands' CSR activities, the resulting CSR perceptions may stabilize over time. A subsequent event, such as the formation of the cobrand, could lead to new attitudes towards the partner brands. The newly-formed cobrand attitude could then spill-over and influence CSR perceptions towards the partner brands. The attitude stability will result in a positive relationship between the prealliance CSR perceptions and post-alliance CSR perceptions towards a partner brand. As suggested by Simonin and Ruth (1998, p 32), "in order to determine whether cobrand attitudes spillover and influence post-alliance perceptions of the partner brands, it is logical to control for the theoretical and predictive perceptions towards the same object (i.e. each partner brand)". If the cobrand is evaluated favorably, then it is likely that the subsequent evaluations of the partner brands' CSR perceptions will also be favourable. The cobrand attitude evaluation, therefore, could lead to variations in post alliance CSR perceptions. The stability of the CSR perceptions of the partner brands post cobranding, however, has not yet been examined. Therefore, it is posited that pre-alliance CSR perceptions will positively influence post-alliance CSR perceptions of the partner brands, leading to the following hypothesis: 
H1: Pre-alliance CSR perceptions toward a partner brand are positively related to post-alliance CSR perceptions toward the same brand $\left(H 1_{A}\right.$ refers to brand $A, H 1_{B}$ refers to brand $B$ ).

Extant research shows that attitudes toward the cobrand have an impact on postalliance attitudes toward the partner brands (Lafferty et al., 2004). For instance, Simonin and Ruth (1998) have shown that attitudes toward the partner brands change positively when consumers are exposed to a favourably evaluated brand alliance. Exposure to the favourably evaluated cobrand based on two partners that are engaged in CSR activities could similarly lead to positive attitudes towards the partners post alliance. Therefore, this study postulates the following hypothesis:

\section{H2: Attitudes toward the cobrand are positively related to post-alliance CSR perceptions toward the partner brands.}

Research in cobranding has confirmed the positive relationship between pre-alliance attitudes towards the partner brands and attitudes toward the cobrand (Simonin and Ruth, 1998; Voss and Gammoh, 2004). In the domain of CSR, Klein and Dawar (2004) suggest that CSR perceptions affect the attribution process itself wherein consumers form perceptions and evaluate the brand accordingly. Since consumers hold perceptions about the CSR activities of the partner brands, the attitude towards the cobrand will be a result of the attributions towards the partner brands CSR activities. Accordingly, CSR perceptions are expected to influence cobrand evaluation directly and confirm the same relationship as proposed in the cobranding domain, resulting in the third hypothesis:

H3: CSR perceptions toward the partner brands are positively related to attitudes toward the cobrand $\left(H 3_{A}\right.$ refers to brand $A, H 3_{B}$ refers to brand $\left.B\right)$

CSR perceptions and the role of perceived fit 
The concept of perceived "fit" between a brand and its extension or between two brands has been shown to elicit positive effects on attitudes in different streams of literature such as brand extensions, sponsorship, and cobranding (e.g., Aaker and Keller, 1990; Simonin and Ruth, 1998). A well-known fit concept is that of product fit, which refers to the extent to which the product categories involved in the formation of the cobrand logically fit together at a functional level (Bouten, Snelders and Hultink, 2011; Simonin and Ruth, 1998). It is important, however, to distinguish between the notion of product category fit as illustrated in the brand extension and in cobranding literature. Whilst in brand extension literature the perceived fit refers to the complementarity between an existing brand and its extension, in cobranding the perceived fit captures the attributes embodied by both partner brands (Simonin and Ruth, 1998). Studies concur that consumers combine their attitudes toward the products offered by each partner brands easily under high fit condition, and a good fit between the product categories elicits more favorable attitudes toward the cobrand (Baumgarth, 2004; Lafferty et al., 2007; Olsen and Lanseng, 2012). A high level of product fit is shown as a determinant of attitudes toward the cobrand (Simonin and Ruth, 1998). Based on the above explanation, this study postulates product fit to be a determinant of attitudes towards a cobrand resulting from CSR-active partner brands. Therefore, the fourth hypothesis is:

H4: Product fit is positively related to attitudes toward the cobrand.

In addition to the fit between the product categories, a fit between the partner brands' unique associations is held in consumer memory. If the perceptions of the partner brands complement each other, consumers establish a connection between the brands at the image level, leading to high brand fit (Bouten et al., 2011). Conversely, brand images which are inconsistent might trigger a causal or attributional search by consumers, and could lead consumers to question why the brands are partners (Simonin and Ruth, 1998). In line with 
congruity theory which states that consumers seek to maintain and re-establish consistent attitudes towards objects, poor brand fit can have a negative impact on consumer cobrand evaluation (Lafferty et al., 2004). Studies in cobranding consistently show the complementarity of the brands is an important variable influencing cobrand evaluation (e.g., Baumgarth, 2004; Washburn et al., 2000, 2004).

The complementarity of brands can also be seen through the lens of CSR perceptions. According to Brown and Dacin (1997), CSR initiatives can bring value to the company through positive consumer responses. These initiatives are shown to differ in their relative influence on consumer attitudes toward the brand (Bhattacharya and Sen, 2004; Grau and Folse, 2007). For instance, philanthropic activities (e.g., donating for a social cause) have been shown to facilitate the greatest positive effect on consumer responses as compared to cause-related marketing (e.g., supporting a cause) and sponsorship (e.g., sponsoring a sports event) (Lii and Lee, 2012). Philanthropic activities demonstrate a significant ability to enhance corporate reputation through CSR perceptions, since they lower the potential of consumer negative thoughts about the company's underlying intentions (Polonsky and Speed, 2001; Webb and Mohr, 1998). Additionally, a high fit between pre-existing brand attitudes and a given CSR initiative is also found to be better integrated into consumer's existing knowledge structures, as it transfers social cause values to the brand while strenghtening the partnership between the firm and its CSR initiatives (e.g., Alcaniz et al., 2010; Becker-Olsen, Cudmore and Hill, 2006; Menon and Kahn, 2003).

The above discussion demonstrates that consumer perceptions towards CSR activities of the partner brands could influence attitudes towards the cobrand and in turn, the compatibility of CSR initiatives undertaken by both partner brands in an alliance. Such complementarity based on CSR perceptions is defined in this study as CSR fit. The rationale for the CSR fit is found in Aaker and Keller's (1990) hierarchy of associations theory, 
wherein it is expected that the symbolism-based assessment of CSR fit will incorporate the image assessment criterion, known as the brand fit. The perceptions towards the CSR activities of the partner brands, however, may not always lead to a good fit, and could raise the question as to what constitutes a good versus poor fit? The fit perceptions are likely to vary according to the combinations of the CSR causes, leading to differential consumer ratings. In this study, a high level of perceived similarity in the partner brands' CSR activities is defined as a good, or positive, fit, and only the good fit condition is examined. Thus, based on the logic for appropriate match between objects, a good fit between the CSR initiatives of the partner brands is expected to generate positive cobrand evaluation. The above reasoning leads to the fifth hypothesis:

H5: CSR fit is positively related to attitudes toward the cobrand.

\section{The moderating role of ethical self-identity}

A number of studies demonstrate that regardless of the level of fit between the brand and the specific cause, CSR perceptions can elicit equally favorable consumer attitudes toward the company (e.g., Berens et al., 2005; Nan and Heo, 2007). This finding can be explained by the fact that CSR activities generate a degree of affect, or emotional reactions that may eliminate any need for logical fit between the company and the specific CSR initiative (Lafferty, 2007). Such findings are supported by the social identity theory according to which individuals choose and support activities that are congruent with salient aspects of their identity (Tajfel, 1982).

The concept of ethical self-identity has its origin in consumer ethics, and it describes individuals' concept and perception of the 'self' (Sparks and Shepherd, 1992). Prior research shows that consumer identification with ethical issues is likely to result in empathy, which in turn impacts their overall attitudes towards an issue (Ellen, Webb and Mohr, 2006; Hunt and 
Vitell, 2006; Shaw and Shiu, 2002a, 2002b). Extending the above to the context of CSR, consumers may support a company's CSR initiatives because they consider CSR issues to be an important part of their self-identity (Shaw, Shiu and Clarke, 2000). This proposition can be supported by explanatory work by Sparks and Shepherd (1992) who found that selfidentity in ethical contexts is a major contributor to intention to behave.

In addition to the above empirical findings in the domain of consumer ethics, selfidentity is found to moderate consumer attitudes towards cause-brand alliances (Lafferty, 2007; Marin et al., 2009). Given the empirical support in different streams of literature, the construct of ethical self-identity can be argued to moderate the evaluation of cobrands resulting from CSR-active partner brands. For example, consumers who identify themselves as being high on ethical concerns may perceive the cobrand and the partner brands differently from those that define themselves as not strongly concerned about ethical issues. The construct of self-identity could, therefore, lead to insights into how consumers' level of ethical self-identity moderates the direct and spill-over effects in cobrands resulting from CSR-active partner brands. Thus, self-identity is likely to play a moderating role in the relationship between CSR perceptions and consumer cobrand attitudes.

In light of the above discussion, varying levels of ethical self-identity are expected to have differential impact towards post-alliance brand perceptions. The theoretical support for the above assertion is found in the attitude accessibility theory proposed by Fazio, Powell and Williams (1989), who suggest that consumers with highly accessible attitudes toward a given product display greater attitude-behaviour correspondence than those with relatively less accessible attitudes. Consumers have differential levels of concern about ethical issues, and those with high concern report high ethical self-identity (e.g., Berens et al., 2005; Shaw et al., 2000; Sparks and Shepherd, 1992). These consumers have high accessibility towards ethical issues and relatively well-established and stable attitudes towards CSR issues. Post-alliance 
CSR perceptions towards the partner brands will, therefore, be strong in the high ethical selfidentity group. It can then be postulated that spill-over effects for the partner brands in the high ethical self-identity group will be strong because of the higher levels of concern towards ethical issues. Conversely, for consumers with low ethical self-identity, the concern for CSR issues will be weak. Accordingly, the sixth hypothesis is as follows:

H6: The effect of the cobrand evaluation on post CSR perceptions will be stronger for high ethical self-identity, and weaker for low ethical self-identity.

The asymmetric characteristic of attitude accessibility (Fazio et al., 1989; Simonin and Ruth, 1998) is expected to affect the strength of relations among other constructs in the model. In particular, a strong relationship is predicted between pre and post CSR perceptions for consumers with high ethical self-identity, given their established concern for CSR issues. By contrast, in lower levels of ethical self-identity, the concerns for CSR issues are not wellestablished and therefore are less accessible and stable. Accordingly, it is hypothesized that:

H7: The effect of pre-alliance CSR perceptions on post-alliance CSR perceptions will be smaller (larger) for lower (higher) levels of consumers' ethical self-identity.

H8: The effect of pre-alliance CSR perceptions on cobrand evaluation will be smaller (larger) for lower (higher) levels of consumers' ethical self-identity.

Interactions between CSR perceptions, CSR fit, and Product fit

In addition to the direct relationships as hypothesized above, the partner brands' CSR activity-generated perceptions may interact with CSR fit to positively impact attitudes towards the cobrand. For instance, if the positively evaluated CSR activity (e.g., Alcaniz et al., 2010; Becker-Olsen et al., 2006) of brand A interacts with high levels of CSR fit, the resulting interaction will significantly impact cobrand evaluation. The rationale for the interaction between CSR perceptions and the CSR fit is that the pre-alliance perceptions 
towards the partner brand's CSR activity could also be integral to the image of the partner brands (Keller, 2009). Following the information integration theory (Anderson, 1983), such pre-alliance information regarding the brands can integrate with the CSR fit perceptions. Consumers are likely to see the image of the CSR activity of the partner brand not only on its own, but also in tandem with the complementarity of the CSR activities between the brands (CSR fit) while evaluating the new cobrand. Therefore, it is expected that the partner brands' CSR perceptions will interact with CSR fit and the interaction will positively and significantly influence cobrand evaluation. In a similar vein, the complementarity of the product categories (product fit) will interact with the CSR activities generated perception of a partner brand to positively and significantly influence attitudes towards the cobrand. The above interaction-based relationships are tested without formal hypotheses, and the results are expected to provide new insights that could be further generalized.

The relationships posited above are presented in the conceptual model in Figure 1.

Figure 1: Conceptual model

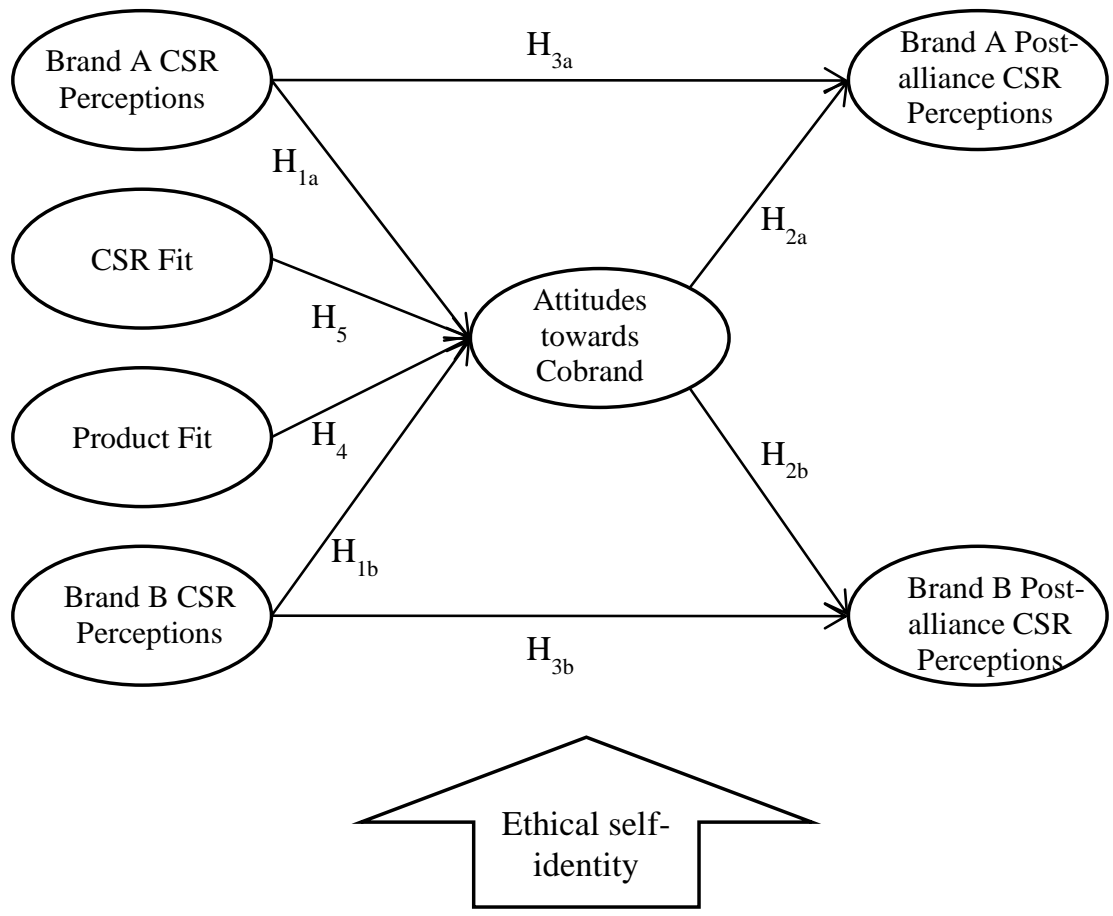




\section{Methodology}

Consistent with prior studies in cobranding (e.g., Baumgarth, 2004; Helmig et al., 2007; Simonin and Ruth, 1998; Singh et al., 2014; Washburn et al., 2000), this study adopts a scenario-based quasi-experiment consisting of hypothetical cobranding alliances between well-known brands. The cobranding scenarios were designed systematically, in consultation with industry experts, and with feedback from consumers. The selection of appropriate market sectors represented the first step. Using criteria such as scope for creation of cobrands, and the diversity of companies and their existing CSR activities, three sectors, namely, beverage, fashion, and technology, were selected. The second step was selecting brands involved in a current CSR activity, from within each sector. The scenarios included real life brands. This decision was based on the reasoning that the real life brands can activate genuine brand affect and perceptions, facilitate responses that correspond to consumer preferences and awareness for the CSR initiatives undertaken by these brands, as well as increase external validity and robustness of the study's findings (consistent with several prior studies, e.g., Keller and Aaker, 1992; Rao et al., 1999; Simonin and Ruth, 1998; Singh et al., 2008).

There are various CSR initiatives that companies undertake in order to fulfil their engagement in CSR. This study identified three types of CSR activities which have been validated in prior research as initiatives that are clearly defined with a specific goal philanthropy, cause-related marketing (CRM), and sponsorship (e.g., Lii and Lee, 2012; Polonsky and Speed, 2001). The selection was also corroborated in the CSR rankings, showing different types of activities (Business in the Community CR Index, 2014). Six sets of cobrands were created between the selected brands, keeping philanthropy as a baseline activity and pairing it with another CSR activity (see Appendix A for textual descriptions of the brands' CSR activities and related hypothetical cobranding scenarios). 
In order to measure and validate the hypothesized relationships, a self-completion questionnaire was developed. The questions were based upon established measures (see measures table in Appendix B). CSR perceptions of the partnering brands (pre- and postalliance, three items each, anchored at 'strongly agree' and 'strongly disagree') were operationalised using established scales from Maignan (2001) and Russel and Russel (2010). For attitudes towards the cobrand and product fit, the three-item scale (anchored at 'negative/positive', 'unfavorable/favorable', and 'bad/good') proposed by Simonin and Ruth (1998) was used. The CSR fit construct was contextualized from the established brand fit measure from Aaker and Keller (1990) and Simonin and Ruth (1998), using a two-item scale (anchored at 'is/is not consistent', and 'is/is not complementary'). In order to facilitate response on the question on CSR fit, the respondents were provided cues about the CSR activities of the partner brands, so that they were able to assess the complementarity of the CSR activities. The ethical self-identity measure (three items, anchored at 'strongly agree' and 'strongly disagree') was adopted from Sparks and Shepherd (1992) and Shaw et al. (2006a and 2006b). All items were measured on a seven-point Likert-type scale.

The respondents first indicated their CSR perceptions towards each of the brand partners, and then answered questions on CSR fit and product fit, after reading the scenario on hypothetical cobrand. In order to mask the purpose of the study, perceptions towards an unrelated brand were sought. The respondents were then presented with the cobrand in the form of pictorial representation and associated textual description of the CSR initiative, and were asked questions related to their cobrand attitudes. Similarly, after exposure to unrelated filler material, respondents were asked about the post-alliance attitudes towards the partner brands. The data were collected in the UK via online survey software Qualtrics. Given that the brands used in the scenarios were well-known to consumers across the population, a 
convenience sample representing a cross-section of demographics (37\% male, $63 \%$ female, age above 21 years), was used. Altogether 318 valid responses were obtained.

In order to test the conceptual model, the data were analysed with the Partial Least Squares-based Structural Equation Modeling (PLS- SEM) (Haenlein and Kaplan, 2004; Hair, Sarstedt, Ringle and Mena, 2012; Tanenhaus et al., 2005) using SmartPLS 2.0 software (Ringle, Wende and Will, 2005). PLS-SEM was adopted due to the exploratory nature of this study, and given its well-established proficiency in generating robust results with small sample sizes (Hair, Hult, Ringle and Sarstedt, 2014). The PLS model estimation provides empirical measures of the relationships between the indicators and the constructs (measurement model), as well as between the constructs (structural model).

\section{Analysis and Results}

The analyses of the results followed the two-stage approach in structural equation modeling suggested by Hair et al. (2012). In the first stage, the measurement model was confirmed (with bootstrap analysis of 1000 subsamples). All constructs in the model were reflective. All constructs for the full sample displayed satisfactory levels of reliability, with Cronbach's alpha ranging between .86 and .94 , and composite reliability (CR) values ranging between 0.91 and 0.96 . Similarly for convergent validity the average variance extracted (AVE) ranged between 0.78 and 0.90 , all within established benchmarks suggested by Fornell and Larcker (1981). The above results are shown in Table 1. Further, discriminant validity is confirmed if the square root of a construct's AVE exceeds its bivariate correlations with other constructs in the model. All constructs met this criterion, as shown in Table 2. 


\begin{tabular}{|c|c|c|c|c|c|}
\hline \multirow[b]{3}{*}{ Construct } & \multicolumn{5}{|c|}{ Average } \\
\hline & & Composite & Variance & Mean & Std. \\
\hline & $\begin{array}{c}\text { Cronbach's } \\
\text { Alpha }\end{array}$ & $\begin{array}{l}\text { Reliability } \\
\text { (CR) }\end{array}$ & $\begin{array}{c}\text { Extracted } \\
\text { (AVE) }\end{array}$ & & Deviation \\
\hline Pre-alliance $\mathrm{CSR}_{\mathrm{A}}$ perception & .860 & .915 & .782 & 2.72 & 1.21 \\
\hline Pre-alliance $\mathrm{CSR}_{\mathrm{B}}$ perception & .857 & .913 & .778 & 2.80 & 1.52 \\
\hline CSR fit & .891 & .949 & .902 & 2.69 & 1.53 \\
\hline Product fit & .864 & .935 & .878 & 2.51 & 1.56 \\
\hline Attitude towards cobrand & .936 & .959 & .886 & 2.79 & 1.67 \\
\hline Post-alliance $\mathrm{CSR}_{\mathrm{A}}$ perception & .901 & .938 & .835 & 2.55 & 1.26 \\
\hline Post-alliance $\mathrm{CSR}_{\mathrm{B}}$ perception & .894 & .934 & .825 & 2.60 & 1.37 \\
\hline
\end{tabular}

Table 2: Testing for Discriminant Validity

\begin{tabular}{|c|c|c|c|c|c|}
\hline & 1 & 2 & 3 & 4 & 5 \\
\hline CSR fit & 0.95 & & & & \\
\hline Product fit & 0.43 & 0.94 & & & \\
\hline Attitude towards Cobrand & 0.42 & 0.53 & 0.94 & & \\
\hline Pre-alliance $\mathrm{CSR}_{\mathrm{A}}$ perception & 0.29 & 0.26 & 0.24 & 0.88 & \\
\hline Pre-alliance $\mathrm{CSR}_{\mathrm{B}}$ perception & 0.38 & 0.33 & 0.39 & 0.60 & .88 \\
\hline
\end{tabular}

Notes:

a) Key: $1=\mathrm{CSR}$ fit; $2=$ Product fit; $3=$ Attitude towards Cobrand; $4=$ Pre-alliance $\mathrm{CSR}_{\mathrm{A}}$ perception; $5=$ Pre-alliance $\mathrm{CSR}_{\mathrm{B}}$ perception.

b) Off diagonals are bivariate correlations, bold diagonals are square root of corresponding AVE.

The analysis of the structural model involved assessment of the $\mathrm{R}^{2}$ values of the dependent variables, the statistical significance of the hypothesized pathways of the model, and the Stone-Geisser $\left(\mathrm{Q}^{2}\right)$ index for predictive relevance of the overall model. The results presented in Table 3 provide evidence of considerable explanatory $\left(\mathrm{R}^{2}\right.$ ranging between .36 and .70) and predictive power $\left(\mathrm{Q}^{2}=\right.$ positive values $)$ of the conceptual model. With the exception of the functional relationships between pre-alliance CSR perceptions of brand A and its impact on cobrand attitude, the hypothesized pathways relating to CSR fit, product fit and pre-alliance CSR perceptions to cobrand attitude, are significant. The same pattern of significant results applies to the pathways linking pre- and post-alliance CSR perceptions of the partner brands, as well as for the pathways between cobrand attitude and post-alliance CSR perceptions towards the partner brands. The results show evidence of spill-over effect, that is, the CSR perceptions of partner brands are strengthened following the cobrand 
formation. Hence, hypotheses $\mathrm{H} 1-\mathrm{H} 5$ are supported, with the exception of $\mathrm{H} 3_{\mathrm{A}}$ being rejected.

In order to examine the interaction effects in the structural mode the two-stage process recommended by Sharma, Durand and Gur-Arie (1981) was followed. The results show a significant impact of the interactions between CSR fit and the CSR activity generated perceptions of the partner brands on attitudes towards the cobrand. The above interaction leads to a negative but significant impact for the partner brand A, and positive and significant impact for the partner brand B. In addition, the interaction between the product fit and CSR activity generated perceptions of the partner brands do not have a significant effect on attitudes towards the cobrand.

Table 3: Standardized regression coefficients (t-values) of hypothesized pathways \& fit indices (full sample, $n=318$ )

\begin{tabular}{|c|c|c|c|c|}
\hline & \multicolumn{2}{|c|}{ Direct effects } & \multicolumn{2}{|c|}{ Direct and } \\
\hline Pre-alliance $\mathrm{CSR}_{\mathrm{A}}$ perception $\rightarrow$ cobrand attitude & & & \multicolumn{2}{|c|}{$.349(2.21)^{* *}$} \\
\hline Pre-alliance $\mathrm{CSR}_{\mathrm{B}}$ perception $\rightarrow$ cobrand attitude & & $* * *$ & \multicolumn{2}{|c|}{$-.360(2.23)^{* *}$} \\
\hline CSR fit $\rightarrow$ cobrand attitude & & & \multicolumn{2}{|c|}{$.368(2.97)^{* *}$} \\
\hline Product fit $\rightarrow$ cobrand attitude & & $* * *$ & \multicolumn{2}{|c|}{$.826(9.04) * * *$} \\
\hline Pre-alliance $\mathrm{CSR}_{\mathrm{A}}$ perception $\rightarrow$ post-alliance $\mathrm{CSR}_{\mathrm{A}}$ & & 4) $* * *$ & \multicolumn{2}{|c|}{$.773(23.75)^{* * *}$} \\
\hline Pre-alliance $\mathrm{CSR}_{\mathrm{B}} \rightarrow$ post-alliance $\mathrm{CSR}_{\mathrm{B}}$ perception & & 4)*** & \multicolumn{2}{|c|}{$.771(23.37)^{* * *}$} \\
\hline Cobrand attitude $\rightarrow$ post-alliance $\mathrm{CSR}_{\mathrm{A}}$ perception & & & \multicolumn{2}{|c|}{$.117(2.96)^{* *}$} \\
\hline Cobrand attitude $\rightarrow$ post $\mathrm{CSR}_{\mathrm{B}}$ perception & & **** & \multicolumn{2}{|c|}{$.141(3.38)^{* * *}$} \\
\hline \multicolumn{5}{|l|}{ Interactions } \\
\hline CSR fit*Pre-alliance $\mathrm{CSR}_{\mathrm{A}}$ perception $\rightarrow$ cobrand attitude & & & \multicolumn{2}{|c|}{$-.225(1.66)^{*}$} \\
\hline CSR fit* Pre-alliance CSR $_{\mathrm{B}}$ perception $\rightarrow$ cobrand attitude & & & \multicolumn{2}{|c|}{$.214(2.24)^{* *}$} \\
\hline Product fit*Pre-alliance $\mathrm{CSR}_{\mathrm{A}}$ perception $\rightarrow$ cobrand attitude & & & \multicolumn{2}{|c|}{$-.086(.733)$} \\
\hline \multirow[t]{2}{*}{ Product fit* Pre-alliance $\mathrm{CSR}_{\mathrm{B}}$ perception $\rightarrow$ cobrand attitude } & & & \multicolumn{2}{|c|}{$.012(.118)$} \\
\hline & $\mathrm{R}^{2}$ & $Q^{2}$ & $\mathrm{R}^{2}$ & $Q^{2}$ \\
\hline Attitudes towards cobrand & .36 & .32 & .42 & .37 \\
\hline Post-alliance CSR perception $_{\mathrm{A}}$ & .65 & .54 & .65 & .54 \\
\hline Post-alliance CSR perception $_{B}$ & .70 & .57 & .70 & .57 \\
\hline
\end{tabular}

Notes:

a) One-tailed tests - * $\mathrm{p}<0.05 ; * * \mathrm{p}<0.01 ; * * * \mathrm{p}<0.001$

b) $\mathrm{A}$ and $\mathrm{B}$ denote the partner brands, while subscripts indicate the specific pathway or relationship; for example Pre-alliance $\mathrm{CSR}_{\mathrm{A}}$ perception $\rightarrow$ cobrand attitude refer to the relationship between prealliance CSR perception of partner brand A with cobrand $\mathrm{AB}$, while Pre-alliance $\mathrm{CSR}_{\mathrm{A}} \rightarrow$ post-alliance $\mathrm{CSR}_{\mathrm{A}}$ perception refer to the relationship between pre and post-alliance CSR perceptions of the partner brand A, etc. 
Assessing the moderating effect of ethical self-identity

In order to test the influence of ethical self-identity as a moderator of the hypothesized relationships, a multisample approach is employed following suggestions by Chin, Marcolin and Newsted (2003) and Henseler and Fassot (2010). These authors suggest that a moderator can be subdivided on the basis of a dichotomization rule, such as in value categories 'low' and 'high'. Following Chin et al.'s (2003) suggestion, a mean split of the total sample was performed. A dichotomization of the 318 respondents on the basis of the index for ethical self-identity was used, which led to a group with high ethical self-identity $(n=134)$, and another group with low ethical self-identity $(n=184)$. Similar to the assessment of the measurement model for the full sample, reliability and validity tests were conducted for the split samples. The constructs displayed satisfactory levels of reliability, with composite pc values ranging from 0.85 to 0.96 . All cross loadings met the benchmark of 0.7 and were highly related to their respective constructs. All AVE values exceeded 0.8 , confirming convergent validity. Similarly, square roots of constructs' AVE were greater than their correlation with other constructs in the model, thus confirming discriminant validity. The proposed asymmetries in ethical self-identity effects were tested by comparing the same path coefficients between the two groups in the sample. Table 4 shows the results from the structural model for the split sample including standardized path coefficients, $t$-values, and $\mathrm{R}^{2}$ values.

Table 4: Testing the Structural Model for High vs Low Ethical Self-Identity Groups 


\begin{tabular}{|c|c|c|}
\hline & $\begin{array}{l}\text { High ethical self- } \\
\text { identity group } \\
(\mathrm{n}=134)\end{array}$ & $\begin{array}{l}\text { Low ethical self- } \\
\text { identity group } \\
\quad(n=184)\end{array}$ \\
\hline Functional Relationships & $\begin{array}{l}\text { Standardized path } \\
\text { coefficients ( } \mathrm{t}- \\
\text { values) }\end{array}$ & $\begin{array}{l}\text { Standardized } \\
\text { path coefficients } \\
\text { (t-values) }\end{array}$ \\
\hline Pre-alliance $\mathrm{CSR}_{\mathrm{A}}$ perception $\rightarrow$ cobrand attitude & $.147(1.64)$ & $-.146(1.57)$ \\
\hline Pre-alliance $\mathrm{CSR}_{\mathrm{B}}$ perception $\rightarrow$ cobrand attitude & $.156(1.61)$ & $.218(2.28)^{*}$ \\
\hline CSR fit $\rightarrow$ cobrand attitude & $-.038(0.55)$ & $.338(3.90)^{* * *}$ \\
\hline Product fit $\rightarrow$ cobrand attitude & $675(9.48) * * *$ & $.197(2.45)^{*}$ \\
\hline Pre-alliance $\mathrm{CSR}_{\mathrm{A}}$ perception $\rightarrow$ post-alliance $\mathrm{CSR}_{\mathrm{A}}$ perception & $.765(14.52)^{* * *}$ & $.777(19.12)^{* * *}$ \\
\hline Pre-alliance $\mathrm{CSR}_{\mathrm{B}} \rightarrow$ post-alliance $\mathrm{CSR}_{\mathrm{B}}$ perception & $.789(15.51)^{* * *}$ & $.760(18.14)^{* * *}$ \\
\hline Cobrand attitude $\rightarrow$ post-alliance $\mathrm{CSR}_{\mathrm{A}}$ perception & $.108(1.72)$ & $.124(2.27)^{*}$ \\
\hline \multirow[t]{2}{*}{ Cobrand attitude $\rightarrow$ post $\mathrm{CSR}_{\mathrm{B}}$ perception } & $.106(1.79)$ & $.164(3.07)^{* *}$ \\
\hline & $\mathrm{R}^{2}$ & $\mathrm{R}^{2}$ \\
\hline Attitudes towards cobrand & .61 & .27 \\
\hline Post-alliance CSR perception $_{\mathrm{A}}$ & .65 & .64 \\
\hline Post-alliance CSR perception $_{B}$ & .71 & .68 \\
\hline
\end{tabular}

Notes:

c) One-tailed tests $-* \mathrm{p}<0.05 ; * * \mathrm{p}<0.01 ; * * * \mathrm{p}<0.001$

d) A and B denote the partner brands, while subscripts indicate the specific pathway or relationship; for example Pre-alliance $\mathrm{CSR}_{\mathrm{A}}$ perception $\rightarrow$ cobrand attitude refer to the relationship between prealliance CSR perception of partner brand A with cobrand $A B$, while Pre-alliance $\operatorname{CSR}_{A} \rightarrow$ post-alliance $\mathrm{CSR}_{\mathrm{A}}$ perception refer to the relationship between pre and post-alliance CSR perceptions of the partner brand A, etc.

The examination of the significance of the hypothesized relationship reveals clear differences between the high and low self-identity groups. Although significant positive relationship between pre and post-alliance CSR perceptions exist for both groups, in the low ethical group attitude toward the cobrand significantly impacts post-alliance CSR perceptions towards both brands, something which is not indicated in the high ethical self-identity group. In addition, only in the low ethical group, CSR fit and CSR perceptions towards brand B explain a sufficient amount of variance in the cobrand construct. These results suggest that both the determinants of attitudes toward the cobrand, as well as the exposure to the cobrand are influenced by the consumer's level of ethical self-identity.

The cobrand has an impact on consumers' post-alliance CSR perceptions only in the low ethical self-identity group (H6). Under conditions of high ethical self-identity, no 
significant direct effect of CSR perceptions on the cobrand was found. Under conditions of low ethical self-identity, the CSR perceptions of partner brand B significantly influence consumer attitudes towards the cobrand. The same positive relationship, however, could not be confirmed for the CSR perceptions towards partner brand A. Altogether, results show that the hypothesized asymmetric relationship does not exist. In other words, under conditions of low ethical self-identity, CSR perceptions explained more variance for cobrand attitudes than under condition of high ethical self-identity. Further, the relationship between prior and postalliance CSR perceptions is significant and positive in both conditions. Therefore, H6 is supported and $\mathrm{H} 7$ and $\mathrm{H} 8$ are rejected.

\section{Discussion and Conclusions}

This study aimed to investigate a hitherto unknown aspect of cobranding, that is, the impact of CSR perceptions on consumer attitudes toward cobrands. The results reveal several important contributions to consumer ethics literature in general, and cobranding and CSR literature in particular. This is the first study to investigate cobranding from a CSR perspective. It provided empirical evidence on the factors influencing consumer evaluation of cobrands while taking into account CSR fit between the partner brands based on nonproduct perceptions. Results show that CSR fit has a positive and significant effect on attitudes toward the cobrand and therefore, is an important antecedent of attitudes towards cobrands. Further, the study shows that product fit, a well-established antecedent of attitudes towards cobrand, is relevant for cobrands resulting from CSR-active partner brands. In addition, this study tested the moderating effect of consumer's ethical self-identity, showing direct and spill-over effects towards cobrand perceptions. The empirical findings show that ethical self-identity moderates consumer attitudes towards the cobrand and post-alliance 
perceptions of the partner brands. These results demonstrate that CSR fit plays a crucial role in understanding consumer perceptions of brand partnerships.

\section{Spill-over effects of CSR perceptions}

The results in the study show that cobranding can modify subsequent CSR perceptions towards the partner brands. This finding demonstrates that cobranding can enhance CSR perceptions as a result of the collaborative effort. A partnership can benefit the CSR perceptions of both partner brands. Each partner brand brings its CSR perceptions to the alliance, and this new context adds value to the perceptions about the brand formed prior to the alliance. This result can be explained by the signaling theory wherein a cobrand signals the CSR perceptions that the partner brands could not signal by themselves (e.g., Kirmani and Rao, 2000; Rao and Ruekert, 1994; Rao et al., 1999). The evidence of positive spillover for cobrands resulting from CSR-active brands is consistent with the mainstream cobranding literature with several examples of studies showing positive spillovers (e.g., Baumgarth, 2004; Bluemelhueber, Carter and Lambe, 2007; Rodrigue and Biswas, 2004; Simonin and Ruth, 1998; Swaminathan et al., 2012).

\section{Impact of CSR perceptions of partner brands on cobrand evaluation}

This research demonstrates that CSR perceptions towards only one partner brand (brand B) have a significant influence on attitudes toward the cobrand. The finding is in contrast with prior cobranding research showing that both partner brands should have an impact on the evaluation of the cobrand (e.g.,; Helmig et al., 2008; Bluemelhueber et al., 2007). Several explanations can be found for this deviating result. One explanation relates to consumers' well-established brand knowledge structures. The brands included in this study are global and highly recognizable leaders in their respective sectors. Moreover, it is worth 
noting that although both partner brands have significant contributions in the CSR domain, in all scenarios brand A experienced some controversies in the past. For example, Nescafe faced negative media coverage for product safety and unethical codes of baby milk promotion over the last decades (Ethical Consumer, 2014). H\&M repositioned itself as an ethical company following negative publicity of bad working conditions in Asia (Clean Clothes Campaign, 2014). These events suggest that due to their inconsistent image over time, the brands might have provoked perceptions of negative intent or hypocrisy. Past CSR research shows that perceived hypocrisy damages consumer attitudes toward the brand by affecting CSR perceptions in a negative way (Wagner, Lutz and Weitz, 2009). By contrast, all brands B (i.e. Coca-Cola; Nike) had consistent commitment to CSR issues whilst making use of a proactive communication strategy (commitment before negative CSR information) as opposed to reactive strategy (protecting brand image after irresponsible actions) as in the case of Nescafe or H\&M. Therefore, this study concludes that a positive relationship between CSR perceptions towards partner brands and attitude toward the cobrand can exist only if the brands are unambiguously perceived as ethical by consumers and follow proactive communications strategies.

CSR fit as a determinant of cobrand evaluations

An interesting finding of this study is the role of the CSR fit concept in influencing consumer attitudes towards cobrands. The results show that CSR fit is an important antecedent of attitudes toward the cobrand. In line with the information integration theory (Anderson, 1983), consumers' prior CSR perceptions toward the partner brands are integrated as a result of the cobrand. The newly-formed CSR perceptions of the alliance, in turn, influence evaluation of the cobrand. CSR fit is confirmed as an important factor influencing the evaluation of cobrands in the full sample as well as in the low ethical self-identity group. 
Surprisingly, CSR fit did not have an impact on consumer attitudes toward the cobrand in the high ethical group. This result could be due to the fact that alliances associated with CSR initiatives provoke additional emotions that are missing in non-CSR brand partnerships. The CSR initiatives might have generated some degree of affect in consumers with high ethical self-identity which, in turn, influenced their cognition (Lafferty, 2007). Thus, consumers' affective reactions towards CSR initiatives might have eliminated any need for a logical fit. The fact that the brands are associated with good causes contributing to society's welfare might instead be a sufficient criterion for consumers with high ethical self-identity to show positive CSR perceptions, and therefore positively evaluate the cobrand.

Hence, this study shows that for consumers with high ethical self-identity, affect and emotional reaction can precede and negate any need for fit between the company's CSR activities. In contrast, for consumers with low ethical self-identity, CSR fit emerges as an important determinant of attitudes toward the cobrand. In this group, the complementarity of the CSR initiatives significantly impact positive evaluation of the cobrand.

\section{Product fit as a determinant of cobrand evaluation}

Another finding of this research relates to the role of product fit as a determinant of attitudes toward the cobrand in the context of CSR. Product fit is a significant antecedent of cobrand evaluation in both the full sample and in the high ethical self-identity group, a finding consistent with past mainstream cobranding studies (e.g., Bouten et al., 2011; Simonin and Ruth, 1998). This result is explained by the fact that the products used in this study are integrated in consumer knowledge structures, for example, the fit emerging from technology brands Canon and software Skype is a result of category compatibility. The close fit between the categories, in turn, have a positive impact on the evaluation of cobrand attitudes. 


\section{Asymmetric effects for consumers with high and low ethical self-identity}

This research demonstrates an asymmetry in the effect of the cobrand on post-alliance CSR perceptions for people with high and low ethical self-identity. The effect of the cobrand on post-alliance CSR perceptions is significant under conditions of low ethical self-identity, but non-significant under conditions of high ethical self-identity. This result suggests that consumers with low ethical self-identity experience greater spill-over effects from the cobrand, as compared to consumers reporting high ethical self-identity. These results are in line with past research on attitude strength (e.g., Fazio et al., 1989), wherein the strong and well-established degree of liking of CSR issues among consumers with high ethical selfidentity might prevent consumers from showing a shift in perceptions of the alliance. On the other hand, the new stimulus provided by the cobrand modifies and enhances the CSR perceptions of consumers with low ethical self-identity, and is explained by the information integration theory (Anderson, 1983).

\section{Pre and post-alliance CSR perceptions}

This study demonstrates that pre-alliance CSR perceptions are positively related to post-alliance CSR perceptions regardless of consumers' level of ethical self-identity. The effect of pre-alliance CSR perceptions on post-alliance CSR perceptions is the same whether consumers hold strong CSR beliefs or not, and these results do not corroborate past research (Fazio et al., 1989; Simonin and Ruth, 1998). One explanation is that the difference between overall evaluation (brand attitude) and symbolic benefit (CSR perceptions) might have contributed to these deviating results. In this regard, Lafferty et al. (2004) found that in cause-brand alliances, prior brand attitudes have a weak impact on post-alliance attitudes in conditions of high familiarity where greater accessibility of attitudes can be observed. These authors explained the results by suggesting that there is a difference between familiarity with 
brands and familiarity with causes. Familiarity with brands is easily developed, as consumers experience the brand through consumption, whereas familiarity with causes is not as easy to establish since it is unlikely for the consumers to have personal experiences with the causes (Lafferty et al., 2004). Extending the above reasoning to the present study, CSR perceptions seem more abstract, and symbolic benefits of the CSR activity may not elicit beliefs that actual consumption of the brand would generate (Bettman and Sujan, 1987). Therefore, the effect of pre-alliance CSR perceptions on post-alliance CSR perceptions for consumers with high ethical self-identity may not necessarily lead to strong attitudes, in comparison with consumers with low ethical self-identity.

\section{Interactions between the partner brands' CSR perceptions, CSR fit and Product fit}

The results for the interaction effects demonstrate that CSR fit interacts with the CSR activities generated perceptions of the partner brands to positively impact attitudes towards the cobrand. The interaction between the two constructs also conforms to the information integration theory (Anderson, 1983), wherein the image resulting from the CSR activity of the partner brand interacts with CSR fit perceptions and positively influences cobrand evaluation. On the other hand, the interaction between product fit and the CSR activities generated perceptions of the partner brands does not have a significant impact on cobrand evaluation. This result shows that consumers assess product fit independently, and it does not relate to the CSR perceptions of the partner brands. The non-significant result presents a fertile avenue for further research involving different types of product categories and the varying levels of fit. In sum, the interaction results indicate a strengthening of the cobrand attitude when CSR fit is taken into account.

\section{Managerial Implications}


The results in this study provide a number of guidelines to business managers. For example, the results demonstrate that exposure to cobrands can significantly enhance CSR perceptions toward the partner brands in an alliance. Therefore, managers can leverage cobranding to position their brands. Cobrands based on CSR-active partner brands have the potential to shift and modify subsequent CSR perceptions toward the partner brands in a positive manner.

For favorable consumer evaluations, a cobrand should ensure product fit and CSR fit. Brand managers need to evaluate the level of fit between the products of both partner brands and test the transferability of their respective categories to cobrand. Additionally, brand owners should take into account the variety of CSR initiatives available and select activities that are likely to elicit more favorable consumer responses.

Brand managers pursuing a cobranding strategy need to consider the characteristics of their target market. As this study demonstrates, consumer characteristics are likely to moderate the direct and spill-over effects of cobrands. Managers are advised to carry out a detailed analysis of their target market and align their strategy according to their consumer's varying levels of ethical self-identity. Managers with a target market of customers with high ethical self-identity should reflect on the compatibility of the product categories rather than the fit between the CSR initiatives. On the other hand, brands with a target market of customers with low ethical self-identity should focus on the symbolic match between the CSR initiatives.

\section{Limitations and Further Research}

The findings in this study are contingent on the following limitations which provide avenues for further research. First, this study designed scenarios with well-established, reallife global brands in order to enhance the external validity and robustness of findings. 
However, studies involving brand perceptions often rely on fictitious brands in order to avoid the influence of pre-existing perceptions relating to the brand. Therefore, future studies might benefit from testing the model by using both real and fictitious brands. Second, a research design with a brand with strong CSR perceptions and a brand with weak (or no) CSR perceptions might be worth investigating as the magnitude of spill-over effects might vary significantly between partners. For example, there should be a significant difference in the extent to which a CSR-active brand such as Body Shop and a brand unknown for its CSR activities contribute to the alliance as well as experience spill-over effects. In this regard, prior negative information about a brand could have an impact on perceptions towards its CSR activity, and this could be factored in a future study. The variability in positive and negative spillovers resulting from CSR perceptions of the partner brands merits further investigation, and could be a useful addition to the so far sparse literature on negative spillovers in cobranding (e.g., James, 2005; Suh and Park, 2009; Till and Shimp, 1998; Votolato and Unnava, 2006).

Third, the CSR fit construct was contextualized from scales borrowed from the existing brand fit construct. A future study could develop and validate a CSR fit construct consisting of original scale items. Fourth, the present study examined the impact of the combinations of CSR activities in terms of CSR fit. The scenarios generally represented good fit of the CSR activities. A future study can examine the impact of variations in fit (e.g., high vs low, positive vs negative, types and nature of CSR causes) by embedding the levels of CSR fit in experimental scenarios.

Additional factors that may have an impact on cobrand attitudes, such as the different communications strategies (proactive vs. reactive), and their influence on the success of the alliance also merit further research. Cobrands comprising CSR-based companies and companies from the so-called 'sin industry' (e.g., automotive, petroleum) might shed light on 
possible negative spill-over effects in cobranding. Further, this study demonstrates the impact of ethical self-identity on the direct and spill-over effects in cobranding, therefore, consumer characteristics are not only integral to the evaluation of cobrands of CSR-active partner brands but should also play a key role in understanding brand partnerships. Another avenue for research could be to test the role of consumer characteristics such as consumer identification with a company. Finally, previous research has established that services are high on intangibility and therefore different from tangible products. Due to the intangible nature of CSR perceptions, investigating services-based CSR alliances could yield interesting results.

Acknowledgments

The author would like to thank Jasmine Rifai and Benedetta Crisafulli for their assistance in data collection and proofreading respectively.

\section{References}

Aaker. D. A. and Keller, K. L. (1990). Consumer evaluations of brand extensions. Journal of Marketing, 54(1), pp. 27-41.

Alcaniz, E. B., Caceres, R. C. and Perez, R. C. (2010). Alliances between brands and social causes: the influence of company credibility on social responsibility image. Journal of Business Ethics, 96 (2), pp. 169-186.

Anderson, J.R. (1983). The Architecture of Cognition. Cambridge: Harvard University Press.

Auger, P., Burke, P., Devinney, T. and Louviere, J. (2003). What will consumers pay for social product features? Journal of Business Ethics, 42(3), pp 281-304. 
Baumgarth, C. (2004). Evaluations of co-brands and spill-over effects: further empirical results. Journal of Marketing Communications, 10(2), pp. 115-131.

Bhattacharya, C. B. and Sen, S. (2004). Doing better at doing good: when, why, and how consumers respond to corporate social initiatives. California Management Review, 47(1), pp. 9-24.

Becker-Olsen, K., Cudmore, A. and Hill, R. (2006). The impact of perceived corporate social responsibility on consumer behaviour. Journal of Business Research, 59(1), pp. 4653.

Berens, G., van Riel, C. B. M. and van Bruggen, G. H. (2005). Corporate associations and consumer product responses: the moderating role of corporate brand dominance. Journal of Marketing, 69(3), pp. 35-48.

Bettman, J. R and Sujan, M. (1987). Effects of framing on evaluation of comparable and noncomparable alternatives by expert and novice consumers. Journal of Consumer Research, 14(2), pp. 141-154.

Bluemelhueber, C., Carter, L. and Lambe, C. J. (2007). Extending the view of brand alliance effects. An integrative examination of the role of country of origin. International Marketing Review, 24(4), pp. 427-443.

Bouten, L. M. , Snelders, D. and Hultink, E. J. (2011). The impact of fit measures on the consumer evaluation of new co-branded products. Journal of Product Innovation Management, 28(4), pp. 455-469.

Brown, T. J and and Dacin, P. E. (1997). The company and the product: corporate associations and consumer product responses. Journal of Marketing, 61(1), pp. 68-84.

Business in the Community (BITC) (2014). Corporate Social Responsibility Index and Rankings. Available at: http://www.bitc.org.uk/our-services/benchmarking/cr-index (Accessed: 24th April, 2014). 
Chin, W. W., Marcolin, B. L., and Newsted, P. R. (2003). A partial least squares latent variable modeling approach for measuring interaction effects: Results from a Monte Carlo simulation study and an electronic-mail emotion/adoption study. Information Systems Research, 14(2), pp. 189-217.

Clean Clothes Campaign (2014). H\&M's infrastructure for the auditing and improvement of working conditions in supplier factories. Clean Clothes Campaign. (http://www.cleanclothes.org) Available at: http://doku.cac.at/hm_english\%5B1\%5D.pdf (Accessed: 27 April, 2014).

Desai, K. K. and Keller, K. L. (2002). The effects of ingredient branding strategies on host brand extendibility. Journal of Marketing, 66(1), pp. 73-93.

Ellen, P., Webb, D. and Mohr, L. (2006). Building corporate associations: consumer attributions for corporate socially responsible programs. Journal of the Academy of Marketing Science, 34(2), pp. 147-157.

Ethical Consumer (2014). Nestle Boycott. Available at: http://www.ethicalconsumer.org/boycotts/boycottslist.aspx\#n (Accessed: 28 April, 2014).

Fornell, C., and Larcker, D. (1981). Evaluating structural equation models with unobservable variable and measurement error. Journal of Marketing Research, 18(1), pp. 39-50.

Fazio, R. H., Powell, M. C. and Williams, C. J. (1989). The role of attitude accessibility in the Attitude-to-Behavior Process. Journal of Consumer Research, 16(3), pp. 280-288.

Gammoh, B. S., and Voss, K. E. (2013). Alliance competence: the moderating role of valence of alliance experience. European Journal of Marketing, 47(5/6), pp. 964-986.

Haenlein, M. and Kaplan, A. M. (2004). A beginner's guide to partial least squares analysis. Understanding Statistics, 3(4), pp. 283-297. 
Hair, J. F., Sarstedt, M. Ringle, C. M., and Mena, J. A. (2012). An assessment of the use of partial least squares structural equation modeling in marketing research. Journal of the Academy of Marketing Science, 40(3), pp. 414-433.

Hair, J., Hult, G., Ringle, C., and Sarstedt, M. (2014). A Primer on Partial Least Squares Structural Equation Modeling (PLS-SEM). Sage Publications, Inc., NY.

He, H. and Li, Y. (2011). CSR and service brand: the mediating effect of brand identification and moderating effect of service quality. Journal of Business Ethics, 100(4), pp. 673688.

Helmig, B., Huber, J. A. and Leeflang, P. S. H. (2008). Co-branding: the state of the art. Schmalenbach Business Review, 60(October), pp. 359-377.

Henseler, J., and Fassott, G. (2010). Testing moderating effects in PLS path models: An illustration of available procedures. In Handbook of Partial Least Squares: Concepts, Methods and Applications in Marketing and Related Fields, V. E. Vinzi, W. W. Chin, J. Henseler, and H. Wang, eds., Berlin: Springer, pp. 713-735.

Hunt, S. D. and Vitell, S. J. (2006). The general theory of marketing ethics: a revision and three questions. Journal of Macromarketing, 26(2), pp. 1-11.

James, D. (2005). Guilty through association: brand association transfer to brand alliances. Journal of Consumer Marketing, 22(1), pp. 14-24.

Kalafatis, S., Remizova, N., Riley, D. and Singh, J. (2012). The Differential Impact of Brand Equity on B2B Co-branding. Journal of Business and Industrial Marketing, 27(8), pp. 623-634.

Kalafatis, S., Riley, D. and Singh, J. (2014). Context Effects in the Evaluation of Business-toBusiness Brand Alliances. Industrial Marketing Management, 43(2), pp. 322-334.

Keller, K. L. (1987). Memory factors in advertising: the effect of advertising retrieval cues on brand evaluations. Journal of Consumer Research, 14(3), pp. 316-333. 
Keller, K. L. (1993). Conceptualizing, measuring, and managing customer-based brand equity. Journal of Marketing, 57(1), pp. 1-22.

Keller, K. L. (2009). Building strong brands in a modern marketing communications environment. Journal of Marketing Communications, 15(2-3), pp. 139-155.

Keller, K. L. and Aaker, D. A. (1992). The effect of sequential introduction of brand extensions. Journal of Marketing Research, 29(1), pp. 35-50.

Klein, J. and Dawar, N. (2004). Corporate social responsibility and consumers' attributions and brand evaluations in a product-harm crisi. International Journal of Research in Marketing, 21(3), pp. 203-217.

Kirmani, A. and Rao, A. R. (2000). No pain, no gain: A critical review of the literature on signaling unobservable product quality. Journal of Marketing, 64(2), pp. 66-79.

Kumar, P. (2005). The impact of cobranding on customer evaluation of brand counterextensions. Journal of Marketing, 69(3), pp. 1-18.

Lafferty, B. (2007). The relevance of fit in a cause-brand alliance when consumers evaluate corporate credibility. Journal of Business Research, 60(5), pp. 447-453.

Lafferty, B., Goldsmith, R. and Hult, T. (2004). The impact of the alliance on the partners: a look at cause-brand alliances. Psychology \& Marketing, 21(7), pp. 509-531.

Lichtenstein, D., Drumwright, M. and Braig, B. (2004). The effects of corporate social responsibility on customer donations to corporate-supported nonprofits. Journal of Marketing, 68(4), pp. 16-32.

Lii, Y. S and Lee, M. (2012). Doing right leads to doing well: when the type of CSR and reputation interact to affect consumer evaluations of the firm. Journal of Business Ethics, 105(1), pp. 69-81.

Luo, X. and Bhattacharya, C.B. (2006). Corporate social responsibility, customer satisfaction, and market value. Journal of Marketing, 70(4), pp. 1-18. 
Luo, X. and Bhattacharya, C.B. (2009). The debate over doing good: corporate social performance, strategic marketing levers, and firm-idiosyncratic risk. Journal of Marketing, 73(6), pp. 198-213.

Luzar, E. and Cosse, K. (2003). Willingness to pay or intention to pay: the attitude-behaviour relationship in contingent valuation. Journal of Socio-Economics, 27(3), pp. 427-444.

Maignan, I. (2001). Consumers' perceptions of corporate social responsibilities: a crosscultural comparison. Journal of Business Ethics, 30(1), pp. 57-72.

Marin, L., Ruiz, S. and Rubio, A. (2009). The role of identity salience in the effects of corporate social responsibility on consumer behavior. Journal of Business Ethics, 84(1), pp. 65-78.

Menon, S. and Kahn, B. (2003). Corporate sponsorships of philanthropic activities: when do they impact perception of sponsor brand? Journal of Consumer Psychology 13(3), pp. 316-327.

Mohr, L. A. and Webb, D. J. (2005). The effect of corporate social responsibility and price on consumer responses. Journal of Consumer Affairs, 39(1), pp. 121-147.

Nan, X. and Heo, K. (2007). Consumer responses to corporate social responsibility (CSR) initiatives. examining the role of brand-cause fit in cause-related marketing. Journal of Advertising, 36(2), pp. 63-74.

Newmeyer, C., Venkatesh, R. and Chatterjee, R. (2014). Cobranding arrangements and partner selection: a conceptual framework and managerial guidelines. Journal of the Academy of Marketing Science, 42(2), pp. 103-118).

Olsen, L. E. and Lanseng, E. J. (2012). Brand alliances: the role of brand concept consistency. European Journal of Marketing, 46(9), pp. 1108-1126. 
Polonsky, M. J. and Speed, R. (2001). Linking sponsorship and cause related marketing: Complementary and conflicts. European Journal of Marketing, 35(11/12), pp. 13611389.

Rao, A. R, Qu, L. and Ruekert, R. (1999). Signaling Unobservable Product Quality Through a Brand Ally. Journal of Marketing Research, 36 (2), pp. 258-268.

Rao, A. R. and Ruekert, R. (1994). Brand alliances as signals of product quality. Sloan Management Review, 36(3), pp. 87-97.

Ringle, C.M., Wende, S., and Will, A. (2005). SmartPLS 2.0 (M3) beta. Hamburg: http://www.smartpls.de

Rodrigue, C. and Biswas, A. (2004). Brand alliance dependency and exclusivity: an empirical investigation. Journal of Product \& Brand Management, 13(7), pp. 477-487.

Russell, D. and Russell, C. (2010). Here or there? Consumer reactions to corporate social responsibility initiatives: Egocentric tendencies and their moderators. Marketing Letters, 21(1), pp. 65-81.

Sharma S., Durand M. R. and Gur-Arie, O. (1981). Identification and analysis of moderator variables. Journal of Marketing Research, 18(3), pp. 291-300.

Shaw, D., Shiu, E. and Clarke, I. (2000). The Contribution of Ethical Obligation and Selfidentity to the Theory of Planned Behaviour: an exploration of ethical consumers. Journal of Marketing Management, 16(8), pp- 879-894.

Shaw, D. and Shiu, E. (2002a). An assessment of ethical obligation and self-identity in ethical consumer decision-making: a structural equation modeling approach. International Journal of Consumer Studies, 26(4), pp. 286-293.

Shaw, D. and Shiu, E. (2002b). The role of ethical obligation and self-identity in ethical consumer choice. International Journal of Consumer Studies, 26(2), pp. 109-116. 
Shaw, D., Berkin, C., Shiu, E., Hassan, L., Hogg, G. and Wilson, E. (2006a), $35^{\text {th }}$ European Marketing Academy Conference (EMAC), Athens, $23^{\text {rd }}-26^{\text {th }}$ May.

Shaw, D, Hogg, G., Wilson, E., Shui, E. and Hassan, L. (2006b). Fashion victim: the impact of fair trade concerns on clothing choice. Journal of Strategic Marketing, 14(4), pp. 427-440.

Sparks, P. and Shepherd, R. (1992). Self-Identity and the theory of planned behavior: assessing the role of identification with green consumerism. Social Psychology Quarterly, 55(4), pp. 388-399.

Simonin, B. L., and Ruth, J. A. (1998). Is a company known by the company it keeps? Assessing the spillover effects of brand alliances on consumer brand attitudes. Journal of Marketing Research, 35(1), pp. 30-42.

Singh, J., Sanchez, G. S. and Bosque, I. R. (2008). Understanding corporate social responsibility and product perceptions in consumer markets: a cross-cultural evaluation. Journal of Business Ethics, 80(3), pp. 597-611.

Singh, J., Kalafatis, S. and Ledden, L. (2014). Consumer perceptions of cobrands: the role of brand positioning strategies. Marketing Intelligence \& Planning, 32(2), pp. 145-159.

Suh, J.-Y. and Park, S.-B. (2009). Successful Brand Alliance and Its Negative Spillover Effect on a Host Brand: Test of the Cognitive Response Hypothesis. Advances in Consumer Research, 36, pp. 243-47.

Swaminathan, V., Reddy, S. K. and Dommer, S. L. (2012). Spillover effects of ingredient branded strategies on brand choice: A field study. Marketing Letters, 23(1), pp. 237251.

Tajfel, H. (1982). Social Psychology of Intergroup Relations. Annual Review of Psychology, 33, pp. 1-39. 
Tenenhaus , M. , Vinzi, V, E., Chatelin, Y. M and Lauro, C. (2005). PLS path Modeling. Computational Statistics \& Data Analysis, 48, pp. 159-205.

Till, B. and Shimp, T. (1998). Endorsers in advertising: The case of negative celebrity information. Journal of advertising, 27(1), pp. 67-82.

Voss, K. and Gammoh, B. S. (2004). Building brands through brand alliances: does a second ally help? Marketing Letters, 15(2/3), pp. 147-159.

Votolato, N. and Unnava, H. (2006). Spill over of negative information on brand alliances. Journal of Consumer Psychology, 16(2), pp.196-202.

Wagner, T., Lutz, R. J. and Weitz, B. A. (2009). Corporate hypocrisy: overcoming the threat of inconsistent corporate social responsibility perceptions. Journal of Marketing, 73(6), pp. 77-91.

Washburn, J. H., Till, B. D. and Priluck, R. (2000). Co-branding: brand equity and trial effects. Journal of Consumer Marketing, 17(7), pp. 591-604.

Washburn, J. H., Till, B. D. and Priluck, R. (2004). Brand Alliance Customer-Based BrandEquity Effects. Psychology \& Marketing, 21(7), pp. 487-508.

Webb, D. J. and Mohr, L. A. (1998). A typology of consumer responses to cause-related marketing: from skeptics to socially concerned. Journal of Public Policy \& Marketing, 17(2), pp. 226-238. 


\section{APPENDIX A: Textual descriptions of the CSR activities and cobranding scenarios}

\section{CSR activities of the selected brands}

Nescafe: Nescafe is a leading brand of instant coffee. Nescafe gives money to support projects aimed at improving the quality of life of people in countries where it operates. For instance, Nescafe donates over 6 million Euros to provide clean water sources, hygiene education, and sanitation services to millions of people throughout Africa. Nescafe also supports HIV \& malaria prevention, access to education, and job creation.

Coca-Cola: Coca-Cola is the leading producer and marketer of soft drinks. Coca-Cola funds projects towards society's welfare. For example, Coca-Cola Europe sponsors Exercise is Medicine (www.exerciseismedicine.org) - a non-profit organization that encourages healthcare professionals to advice patients on the importance of physical activity. The initiative has established community-based networks to promote physical activity. Coca-Cola's support has meant that the networks are flourishing and the community programs are reaching thousands more.

$H \& M: H \& M$ is a Swedish global retail-clothing company, known for its fast-fashion clothing. H\&M gives money to support projects aimed at improving the quality of life of people in countries where it operates. For instance, H\&M donated over 6million Euros to help the Children's Centre in China. The donation assists the Centre in its work to address children's rights issues in businesses across the country. $\mathrm{H} \& \mathrm{M}$ also donates clothing and supports the funding of young people in the sewing industry.

Nike: Nike is a global producer of athletic footwear, apparel and sport equipment. Nike funds projects towards society's welfare. For example, Nike has launched a sportswear collection called Sport Against AIDS. The aim of the collection is to increase awareness about AIDS among youth. Over $25 \%$ of the sales are donated towards HIV/AIDS prevention projects. The money raised is donated to HIV/AIDS prevention projects such as YouthAIDS, UNFPA and MTV Staying Alive Foundation.

Canon: Canon is a leading provider of consumer, business-to-business, and industrial digital imaging solutions. Canon donates money to support projects aimed at promoting the cultural and educational development of young people in countries where it operates. For instance, Canon donates over 6 million Euros to foster the fine arts such as painting, sculpture, music, and literature in Europe. In addition, Canon gives a number of research grants to promote scientific relations between Europe and Japan.

Skype: Skype is a voice-over-Internet Protocol service and software application. Skype funds projects towards society's welfare. For example, Skype provides a bespoke, low-bandwidth version of the popular video-chat software, to locations serviced by UNHCR aid workers. Aid workers are often separated from their families for months at a time, without any facilities for communication. The new technology is designed to provide a link for aid workers back to their own support groups, friends and families. To help to fund this effort, Skype hosts a fundraising button where ordinary Skype users donate money for providing computer technology for millions of refugees who have lost their homes.

\section{Cobranding Scenarios}

Coca-Cola and Nescafe

Cobranding Scenario: The instant coffee manufacturer Nescafe teams up with beverage manufacturer Coca-Cola in order to introduce a new product called NesCoke. This partnership combines the expertise of the instant coffee producer Nescafe and the natural flavoring formula of Coca-Cola to develop the first real supercharger, a natural energy boost which boosts mental alertness and physical energy while retaining the unique tastes.

Nike and $H \& M$

Cobranding Scenario: Nike teams up with fashion retailer H\&M in order to introduce a long-term sports clothing partnership Nike for $H \& M$. The partnership is inspired by the idea of delivering young people premium sportswear at affordable prices. Through this clothing line, the sporting spirit of Nike and the latest fashion trends of H\&M can reach millions of people around the world.

Canon and Skype

Cobranding Scenario: Canon teams up with Skype to introduce the first tablet featuring projector and motion control. This new futuristic tablet designed by the imaging experts Canon and the communication experts Skype incorporates a touch screen panel that slides up to reveal a second touch screen which serves both as monitor and keyboard. The tablet features a built-in projector ideal for office presentations or bigscreen movie watching, as well as pen stylus that doubles as a remote control. The built-in camera and microphone enable users to control basic features via voice or hand movement. This gesture control feature 
enables users to interface with the tablet and interact naturally on Skype without any mechanical devices, with high quality images.

\section{APPENDIX B: Measures and Sources}

\begin{tabular}{|c|c|c|}
\hline Construct & Items & Source \\
\hline $\begin{array}{l}\text { Partner brand } \\
\text { CSR perceptions }\end{array}$ & $\begin{array}{l}\text { (Brand name) takes responsibility for the society and } \\
\text { sets high standards for itself. } \\
\text { (Brand name) plays a role in our society that goes } \\
\text { beyond mere generation of profits. } \\
\text { (Brand name) plans for their own long-term business } \\
\text { success as well as society's welfare. }\end{array}$ & $\begin{array}{l}\text { Russel and Russel (2010) } \\
\text { Maignan (2001) }\end{array}$ \\
\hline CSR fit & $\begin{array}{l}\text { How would you rate the partnership based on Brand } \\
\text { Name A making direct donations to support socially } \\
\text { responsible projects and Brand Name B promotion of } \\
\text { encouraging consumers to donate money?/ and Brand } \\
\text { Name B sponsoring X to support Y? }\end{array}$ & $\begin{array}{l}\text { Aaker and Keller (1990) } \\
\text { Simonin and Ruth (1998) }\end{array}$ \\
\hline Product fit & $\begin{array}{l}\text { How would you rate the partnership between a } \mathrm{X} \\
\text { manufacturer and } \mathrm{Y} \text { manufacturer/provider? }\end{array}$ & $\begin{array}{l}\text { Aaker and Keller (1990) } \\
\text { Simonin and Ruth (1998) }\end{array}$ \\
\hline $\begin{array}{l}\text { Attitude towards } \\
\text { the cobrand }\end{array}$ & $\begin{array}{l}\text { I will describe my attitude toward the new product as } \\
\text { I think of the new product as } \\
\text { If you were to use the product what would be your } \\
\text { attitude towards it? }\end{array}$ & Simonin and Ruth (1998) \\
\hline $\begin{array}{l}\text { Ethical Self } \\
\text { identity }\end{array}$ & $\begin{array}{l}\text { As a consumer I think of myself as socially } \\
\text { responsible. } \\
\text { I think of myself as someone concerned about a } \\
\text { company's activities that benefits the society. } \\
\text { As a consumer I am orientated towards buying } \\
\text { products that are made keeping the society's welfare in } \\
\text { mind. }\end{array}$ & $\begin{array}{l}\text { Shaw et al. (2006a) } \\
\text { Sparks and Shepherd (1992) }\end{array}$ \\
\hline
\end{tabular}

